\title{
Gene-nutrient interactions and susceptibility to human obesity
}

\author{
Joseph J. Castillo, Robert A. Orlando and William S. Garver
}

\begin{abstract}
A large number of genome-wide association studies, transferability studies, and candidate gene studies performed in diverse populations around the world have identified gene variants that are associated with common human obesity. The mounting evidence suggests that these obesity gene variants interact with multiple environmental factors and increase susceptibility to this complex metabolic disease. The objective of this review article is to provide concise and updated information on energy balance, heritability of body weight, origins of gene variants, and gene-nutrient interactions in relation to human obesity. It is proposed that knowledge of these related topics will provide valuable insight for future preventative lifestyle intervention using targeted nutritional and medicinal therapies.
\end{abstract}

Keywords: Energy balance, Gene-nutrient, Heritability, Metabolism, Obesity

\section{Background}

The most recent report from the Centers for Disease Control and Prevention indicates that $16.9 \%$ of children and adolescents (2 to 19 years of age) and 34.9\% of adults (20 years of age and older) have obesity as defined by a body mass index (BMI) greater than the ageadjusted 95th percentile and $30 \mathrm{~kg} / \mathrm{m}^{2}$, respectively [1]. To determine the molecular basis for obesity that has reached epidemic proportions in the USA and other developed countries, a large number of genome-wide association studies (GWAS) have been performed to identify obesity gene variants that increase susceptibility to this common metabolic disease [2-14]. These GWAS and subsequent transferability studies, in addition to candidate gene studies performed in diverse populations around the world, have identified gene variants that are associated with common human obesity [6, 15-18]. To date, approximately 140 obesity susceptibility genes have been found to be associated with measures of adiposity (BMI, body fat percentage, and/or waist circumference), and the recent progress is being made to define the pathophysiology of human of human obesity [19]. A chromosomal ideogram showing the loci of these obesity

\footnotetext{
* Correspondence: wgarver@unm.edu

Department of Biochemistry and Molecular Biology, School of Medicine,

University of New Mexico Health Sciences Center, Albuquerque, NM 87131-0001, USA
}

(c) The Author(s). 2017 Open Access This article is distributed under the terms of the Creative Commons Attribution 4.0 International License (http://creativecommons.org/licenses/by/4.0/), which permits unrestricted use, distribution, and reproduction in any medium, provided you give appropriate credit to the original author(s) and the source, provide a link to the Creative Commons license, and indicate if changes were made. The Creative Commons Public Domain Dedication waiver (http://creativecommons.org/publicdomain/zero/1.0/) applies to the data made available in this article, unless otherwise stated. susceptibility genes is provided (Fig. 1). The obesity epidemic is a recent manifestation that has occurred during the past few decades; and not all individuals or populations are adversely affected, thereby suggesting differences based on genetic variability and interaction with environmental factors [20-22]. The combined environmental factors comprising the "obesogenic environment" include dietary nutrients, age, gender, ethnicity, duration of sleep, amount of physical activity, sedentary behavior, stress, smoking, alcohol consumption, use of medication, and depression. It is generally accepted that, of these environmental factors, a primary cause for susceptibility to obesity is through gene-nutrient interactions. The importance of gene-nutrient interactions in promoting obesity and other complex metabolic diseases is evidenced by the rapidly emerging scientific disciplines of nutritional genetics (nutrigenetics) and nutritional genomics (nutrigenomics) that may provide more effective personalized healthcare [23]. It should be noted that a number of brief review articles that focus on gene and environment interactions in relation to obesity have recently been published [22, 24-26].

\section{Energy balance}

The cause of weight gain has often been considered in terms of positive energy balance; the components of which include increased energy intake, decreased energy 


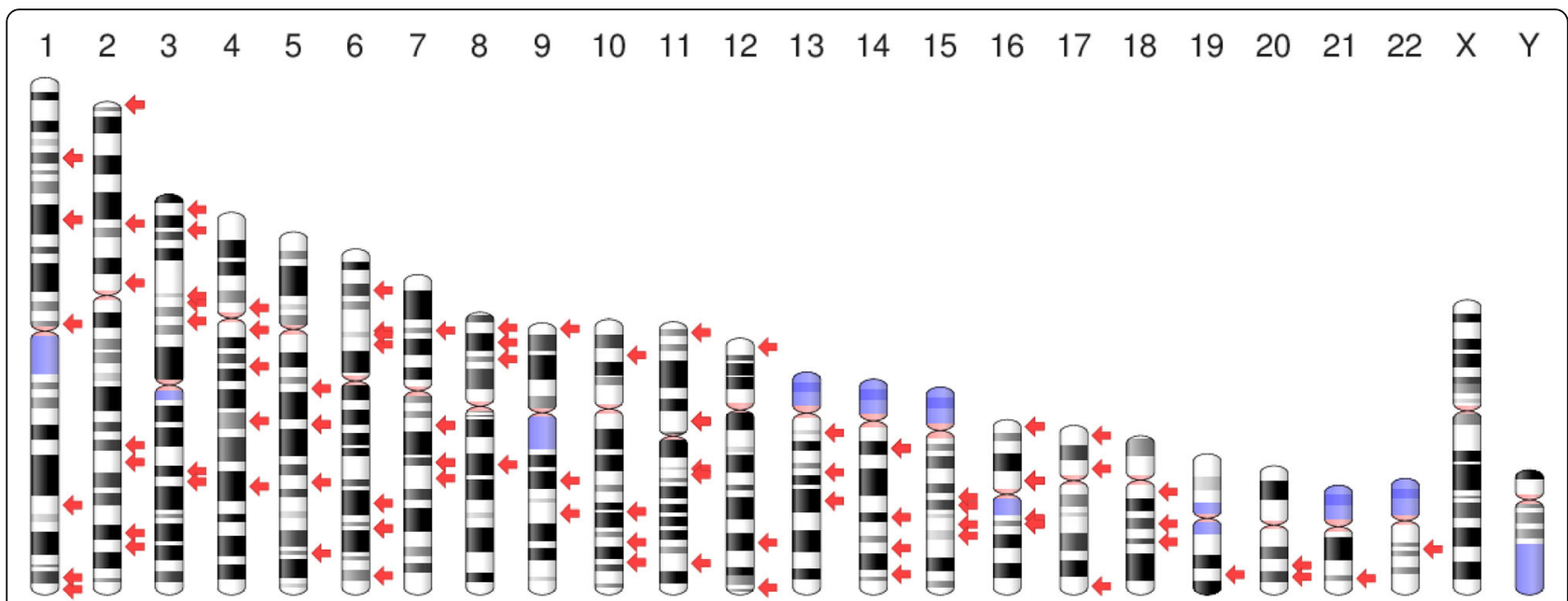

Fig. 1 Chromosomal ideogram of human obesity susceptibility genes. The chromosomal loci for 127 obesity susceptibility genes are provided using a chromosomal ideogram and denoted by red arrows

output, and energy deposition [27]. When energy in the form of calories from food and drink is greater than energy output resulting from (i) resting metabolic rate, (ii) absorption and metabolism of dietary nutrients, (iii) heat production or thermogenesis, and (iv) physical activity, a state of positive energy balance results to promote deposition of triacylglycerol within adipose tissue. In contrast, when energy in the form of calories from food and drink is less than energy output, a state of negative energy balance results to promote lipolysis of triacylglycerol and mobilization of fatty acids from adipose tissue. It should be noted that although the physical laws of thermodynamics provide exact values for these energy transformations, the relative sign and magnitude of these values does not provide information concerning the physiological basis responsible for changes in energy balance [28, 29]. Moreover, although incapable of being measured using current technology, mathematical models have predicted that even small energy surpluses or deficits $(\sim 1 \%)$ over time results in weight gain or weight loss, respectively $[28,30]$.

\section{Heritability of body weight and interaction with environmental factors}

A study performed by Sir Francis Galton over 100 years ago provided the first evidence suggesting that measures of growth (height and body weight) may be heritable [31]. Since that time, the Hereditary Abilities Study, which represented the first comprehensive study performed in the USA to investigate heritability of physical traits, indicated that the greater part for variance of heritability was genetic [32]. This finding was consistent with several other studies, indicating a high heritability of body weight among twins that may or may not have been influenced by interaction with the environment [33-35]. A more recent study has reported that both BMI and waist circumference are of high heritability (77\%), with only modest environmental effects for children living in an obesogenic environment [36]. With respect to the variance of heritability for BMI, a systematic review of twin studies (140,525 twins) and family studies (42,968 family members) indicated a wide range (47 to 90\%) of heritability resulting from population differences [37]. The population differences affecting variance of heritability for BMI has stimulated an interest in understanding how obesity susceptibility genes interact with environmental factors to increase weight gain, in what has formally become known as "gene-environment interactions," defined as a response or adaptation to an environmental agent, a behavior, or a change in behavior, conditional to the genotype of the individual [38]. For example, a study using 12 monozygotic twins who consumed a $1000 \mathrm{kcal} /$ day surplus of calories for a period of 100 days while maintaining a sedentary lifestyle demonstrated a gene-nutrient interaction in relation to weight gain [39]. The results from this study showed a significant within twin-pair resemblance in adaptation to the excess calories ( $\geq 3$ times more variance in response between twin-pairs than within twin-pairs) indicating that genetic susceptibility must have influenced the weight gain. Moreover, a study designed to assess genetic and environmental influences using 114 monozygotic twins, 81 dizygotic twins, and 98 virtual twins (same age but unrelated siblings) indicated that genetic susceptibility contributed $\sim 65 \%$ to heritability for BMI [40]. The heritability of childhood obesity was also closely examined and confirmed in a study using 8234 children that demonstrated a fourfold increase in risk for childhood 
obesity if one parent was obese and a tenfold increase risk for childhood obesity if both parents were obese [41]. Therefore, it is now accepted that heritability can contribute an estimated $40-70 \%$ to the variation of BMI within populations [42]. It should also be noted that genetic architecture for different forms of obesity, whether rare Mendelian (syndromic and non-syndromic) or non-Mendelian (common) obesity, are believed to display variable phenotypes due to interactions with other genes [43-45].

\section{Missing heritability}

The "common disease, common variant" hypothesis states that genetic risk for common diseases is due to variants of high frequency [46, 47]. It was once thought that common variants of high frequency would explain common disease heritability, defined as the proportion of phenotypic variance in a population due to additive genetic factors. However, after identifying hundreds of different variants associated with common diseases, the combination of variants were found to account for only a small proportion of the estimated heritability [48]. In other words, although the estimated heritability for BMI within populations was $40-70 \%$ (heritability inferred indirectly from population data and provided in the denominator), only a few percent of the actual heritability was accounted for through the combined phenotypic effect size or penetrance of known variants (heritability determined directly from effect sizes and provided in the numerator) [11, 49]. Thus, there was increasing concern that identification of "missing heritability," or what has more appropriately been termed "hidden heritability," would be necessary to understand how variants contribute to common diseases for successful translation of this information into clinical practice [50-52]. It is speculated that the identified GWAS variants may be in partial linkagedisequilibrium with low-frequency variants with larger phenotypic effect sizes, thereby accounting for the missing heritability [53-55]. Although some lowfrequency variants of intermediate effect size were found to exist in partial linkage-disequilibrium with GWAS variants, other studies suggest that these rare variants are unlikely to account for the missing heritability [56-60]. Moreover, it was proposed that the amount of missing heritability was overestimated and therefor represented as "phantom heritability" and that unidentified gene interactions (gene-gene and gene-nutrient) may account for any remaining heritability [61]. Finally, in hopes of resolving the case of missing heritability for common diseases, studies now indicate that imputed variants are capable of accounting for a large proportion $(\sim 30 \%)$ of the estimated heritability for body weight, with the remaining proportion likely accounted for by unidentified gene interactions $[62,63]$.

\section{Thrifty and drifty genotype hypotheses}

Consistent with obesity susceptibility gene variants interacting with an obesogenic environment to increase obesity, James V. Neel proposed the thrifty genotype hypothesis based on positive selection (adaptation) of "thrifty genes" resulting from seasonal food shortages and episodic famines during human evolution $[64,65]$. A number of years later, John R. Speakman proposed the drifty genotype hypothesis based on neutral selection (genetic drift) of "drifty genes" resulting from predation release characterized by liberation from predation pressures due to the advent of fire and development of more advanced weapons technology, thereby, in effect, increasing the upper limit of body weight set points [66, 67]. In support of both these hypotheses, commentaries published by experts in the field suggest that positive and neutral selection of gene variants has occurred during human evolution to optimize efficient storage of food energy for later use when food becomes limiting [68-70]. This commentary is also evidenced by a recent study performed with 9416 individuals in 14 European countries indicating that although environmental differences masked genetic differentiation for BMI, it was determined that $8 \%$ of the captured additive genetic variance for BMI was reflected in population genetic differences [71]. However, some studies have questioned the thrifty genotype hypothesis due to the high prevalence of obesity within certain populations, such as those populations in the South Pacific, because past seasonal food shortages and episodic famines are believed not to have occurred, and that a recent comprehensive study performed using signatures of positive selection at obesity susceptibility gene variants did not find evidence for the "thrifty gene" hypothesis [72, 73]. However, other studies have provided evidence of "thrifty gene variants" present within the CREBFR gene among Samoans and the PPARGC1A gene among Tongans in the South Pacific, thereby explaining high rates of obesity among these two populations $[8,74]$. Therefore, it is anticipated that the intellectual debate concerning origin of obesity susceptibility genes will continue.

\section{Dietary macronutrients}

The obesogenic environment consists of a complex interplay of contributing factors that influence behavior effecting dietary choice, physical activity, and/or metabolism responsible for maintaining energy balance [75]. A number of studies suggest that both sedentary behavior (viewing television, playing video games, doing cognitive work, and listening to music) and reduced overall physical activity in addition to shorter sleep duration 
promote the overconsumption of dietary nutrients, particularly fats and refined carbohydrates [76-80]. The increased consumption of a high-fat diet, particularly a high-fat diet enriched with saturated fatty acids, has been found to be strongly associated with increased adiposity in children [81, 82]. Moreover, another recent study performed using 810 participants indicated a highly significant association of saturated fatty acid consumption (but not plant protein, carbohydrates, or other types of fat) at 6 months with body weight at 18 months of age [83]. Consistent with these results, obesity susceptibility genes have been reported to preferentially interact with saturated fatty acids, but not monounsaturated fatty acids or polyunsaturated fatty acids, to promote weight gain $[84,85]$. For these reasons, it is widely accepted that high-fat diets, characterized by enhanced palatability and high energy density, may have a primary role for the obesity epidemic. However, it should also be noted that increased consumption of carbohydrates, particularly refined carbohydrates and sugar-sweetened beverages, during the past 30 years also parallels the increased prevalence of obesity [86-88].

\section{Susceptibility genes for human obesity}

Over the course of the decade (1996-2005) preceding GWAS, an extensive amount of work was performed to identify susceptibility genes for human obesity. The culmination of these studies resulted in the identification of 140 candidate susceptibility genes [89]. However, to date only a limited number $(\sim 25 \%)$ of these obesity susceptibility genes have been validated using independent studies. These genes now represent a comprehensive list of obesity susceptibility candidates that are associated with measures of adiposity (BMI, body fat percentage, and waist circumference) [42, 90-92]. It should be noted that in most cases, the biological function of the encoded proteins and gene products derived from these obesity susceptibility genes remains undefined and therefore further studies must be performed using cells grown in culture, animal models, and diverse ethnic populations before development of targeted nutritional or medicinal therapies.

\section{Gene-nutrient interactions that promote obesity}

The best characterized obesity susceptibility gene known to interact with a dietary nutrient that predisposes to weight gain was identified using a candidate gene approach followed by a number of population-based studies. The apolipoprotein A2 (APOA2) gene is a member of the apolipoprotein multigene family for which the encoded APOA2 protein is associated with high-density lipoprotein (HDL), which modulates activity of lipoprotein lipase to influence liver lipogenesis and adipose lipolysis [93-96]. An initial study indicated that individuals who are homozygous affected for the loss-of-function APOA2 variant (rs5082) had increased measures of adiposity (body weight, BMI, and waist circumference) characterized with increased consumption of food composed of fat and protein compared to individuals who are homozygous normal or heterozygous for this gene variant [97]. A second study identified an association between homozygous affected individuals for the same gene variant and consumption ( $\geq 22 \mathrm{~g} /$ day) of saturated fat (but not unsaturated fat) compared to individuals homozygous normal or heterozygous for this gene variant [98]. A third study indicated an interaction between this gene variant and consumption $(\geq 22 \mathrm{~g} /$ day) of saturated fat (but not unsaturated fat) resulting in a $6.8 \%$ greater BMI compared to individuals homozygous normal or heterozygous from his gene variant in the same population [99]. And finally, the physiological basis for the APOE gene variant and saturated fat was shown to result from behavioral changes that prevented weight loss (do not skip meals) and less likelihood to exhibit protective behavior (do not plan meals) based on the modulation of plasma ghrelin [100]. A more recent study has also reported that physical activity can diminish the genetic effect of a different fat mass and obesityassociated (FTO) gene variant (rs1421085) for adiposity by $36-75 \%$ in a longitudinal multi-ethnic group consisting of 17,423 individuals [22]. Finally, the GWAS that identified the FTO gene also identified the NiemannPick $\mathrm{C} 1$ (NPC1) gene to be associated with morbid-adult obesity in European populations [7]. When this study was published, it was unknown whether the NPC1 gene risk variants (644. $>\mathrm{G}$ encoding His215Arg and $2572 \mathrm{~A}>\mathrm{G}$ encoding Ile858Val) increased or decreased NPC1 protein function. To address this question and further investigate the NPC1 gene in relation to obesity, the BALB/cJ Npc1 mouse model was used possessing a retroposon insertion that prematurely terminated protein translation, thereby producing a non-functional truncated NPC1 protein [101-103]. The results indicated that compared to the Npc1 homozygous normal $\left(\mathrm{Npc}^{+/+}\right)$mice, the $\mathrm{Npc1}$ heterozygous $\left(\mathrm{Npc1}^{+/-}\right)$mice with decreased gene dosage were susceptible to weight gain when fed a high-fat diet, but not when fed a low-fat diet [104]. This study was extended using BALB/cJC57BL/6J hybrid $\mathrm{Npc1}^{+/-}$mice that were also susceptible to weight gain and impaired glucose tolerance when fed a high-fat diet compared to hybrid $\mathrm{Npc}^{+/+}$mice fed the same diet [105]. Moreover, a subsequent study found that the $\mathrm{C} 57 \mathrm{BL} / 6 \mathrm{~J} \mathrm{Npcl}^{+/}$mice are susceptible to weight gain when fed a high-fat diet compared to C57BL/6 $\mathrm{Npc1}^{+/+}$mice fed the same diet [106]. An independent study has since been reported that rare human NPC1 gene loss-of-function mutations among male heterozygotes (but not female heterozygotes) have a 
significantly higher BMI compared to matched controls and that $\mathrm{Npc1}^{+/-}$mice fed a HFD have significantly increased fat storage compared to $\mathrm{Npc}^{+/+}$ mice fed the same diet [107]. The physiological basis for the Npc1 gene-nutrient interaction has recently been characterized by increased liver glycolysis and lipogenesis with an accumulation of hepatic triacylglycerol and cholesterol, in combination with decreased white adipose tissue activation of hormonesensitive lipase and decreased triacylglycerol lipolysis [108]. In support of these results, cellular energy metabolism studies indicated that $\mathrm{NpCl}^{+/-}$fibroblasts had significantly increased glycolysis and lipogenesis in addition to significantly decreased substrate (glucose and endogenous fatty acid) oxidative metabolism resulting in an accumulation of triacylglycerol and cholesterol (Fig. 2). Finally, instead of examining just one obesity susceptibility gene and interaction with a dietary nutrient, a relatively large number of validated obesity susceptibility genes (32) were examined using a genetic risk score that was found to interact with a dietary nutrient. The first study used a combined cohort of 6934 women from the Nurses' Health Study (NHS) and 4423 men from the Health Professionals Follow-Up Study (HPFS) which indicated an increase in relative risk of 1.19 for less than one serving per month of a sugar-sweetened beverage, 1.67 for one to four servings per month, 1.58 for two to six servings per month, and 5.06 for one or more servings per day [109]. A subsequent study using a genetic risk score and combined cohort indicated an increase in relative risk of 1.61 for less than one serving of fried food per week, 2.12 for one to three servings per week, and 2.72 for four or more servings per week [110]. In yet a third study, a genetic risk score of 32 obesity susceptibility genes was used to determine interaction with self-reported intake of various foods (healthy and unhealthy) using 18 combined cohorts of European ancestry (68,317 individuals) [21]. Interestingly, although there was no significant gene-diet

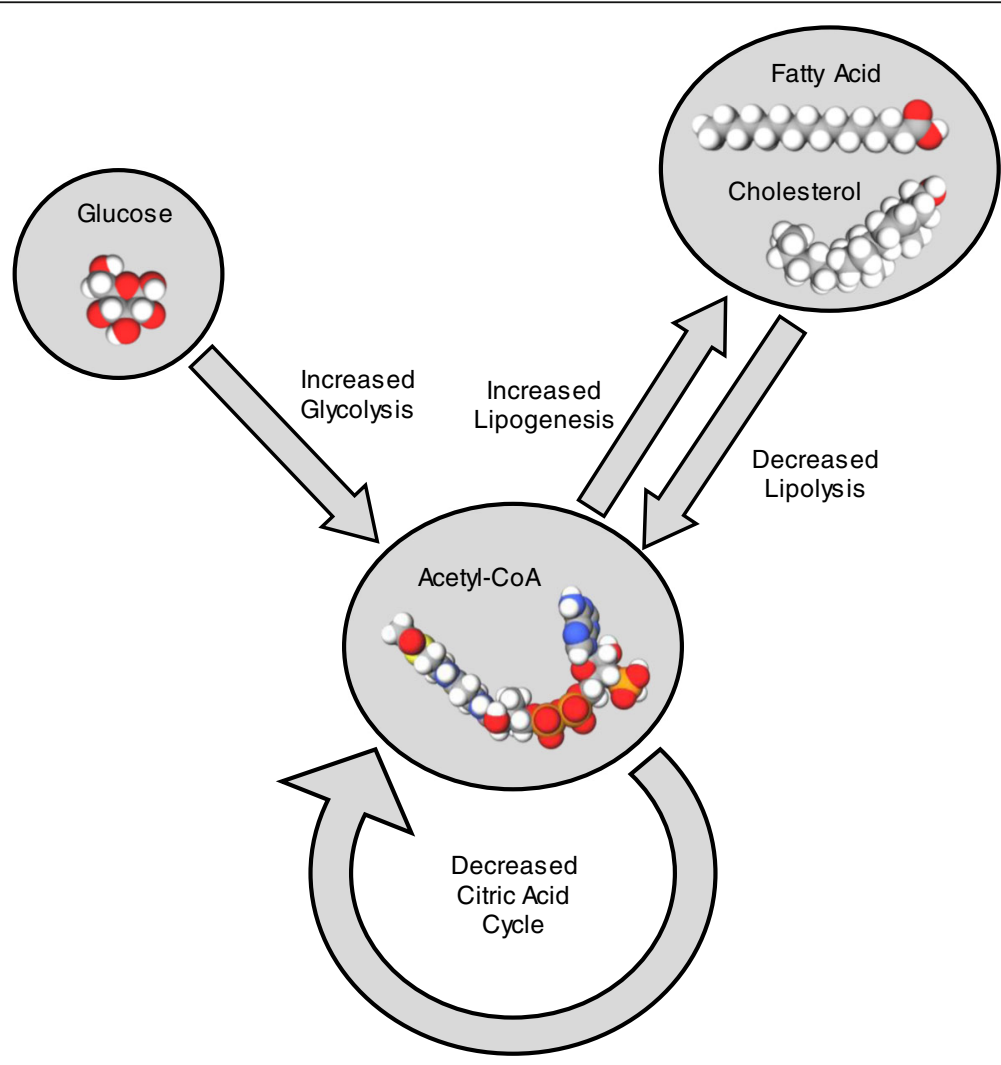

Fig. 2 A general diagram showing the physiological basis responsible for the NPC1 gene-nutrient interaction that promotes weight gain and susceptibility to obesity. Mouse model tissues (liver and adipose) and fibroblasts grown in culture indicate (i) increased glycolysis (oxidation of glucose and conversion to pyruvate in the cytoplasm), (ii) decreased oxidative metabolism (conversion of pyruvate to acetyl-CoA and condensation with oxaloacetate to produce citrate in the mitochondria), (iii) increased lipogenesis pathway (transport of citrate from the mitochondria and conversion to acetyl-CoA and malonyl-CoA for lipid (cholesterol and fatty acid) synthesis in the cytoplasm), and (iv) decreased lipolysis pathway (transport of fatty acid from the cytoplasm and conversion of fatty acid to acetyl-CoA in the mitochondria) 
interaction detected using the genetic risk score for obesity traits (BMI), the results did reveal that two genes (LRRN6C and MTIF3) for obesity traits were actually stronger for individuals consuming healthy foods.

\section{Nutritional and pharmacological intervention}

The current literature clearly indicates that public health interventions are unable to achieve success in long-term weight loss. A basic science approach must be incorporated to more directly address behavioral and physiological reasons for the continuing obesity epidemic [111-113]. The goal for successful nutritional and pharmacological intervention of obesity depends on delineating the physiological basis for how obesity susceptibility genes promote positive energy balance and weight gain responsible for obesity. For instance, the FTO and melanocortin 4 receptor (MC4R) gene variants tend to increase preference for calorie-dense foods enriched with fat and decrease satiety. Although nutritional therapies have not yet been identified that stimulate regions of the brain (arcuate nucleus of the hypothalamus) to promote satiety for individuals harboring these gene variants, a recent study has reported that a new pharmacological agonist (setmelanotide) has been successful in producing sustained reduction in hunger and body weight $(51.0 \mathrm{~kg}$ after 42 weeks in one patient and $20.5 \mathrm{~kg}$ after 12 weeks in a second patient) for patients with proopiomelanocortin deficiency as a result of treatment [114]. Moreover, other pharmacological therapies that are being used to treat obesity include orlistat (Xenical), lorcaserin hydrochloride (Belviq), phentermine and topiramate (Qsymia), bupropion and naltrexone (Contrave), and liraglutide (Saxenda). With respect to the NPC1 gene that interacts with a high-fat diet to cause dysregulation of differential energy metabolism pathways, different therapies will be required to limit hepatic lipogenesis and adipose lipolysis. Of course, for any of the obesity susceptibility genes and encoded proteins that are now being investigated, the overall goal of achieving complete efficacy for nutritional and pharmacological interventions will be modeled after the success of recombinant leptin for those individuals with congenital leptin deficiency [115]. Finally, in closing this section, it should be noted that all macronutrients (carbohydrates, protein, and fat) have unique properties that will impact regulation of energy metabolism genes and/or encoded protein to affect whole-body energy balance.

\section{Conclusions}

The current epidemic of obesity represents a complex metabolic disease characterized in part by the interaction of obesity susceptibility gene variants with dietary nutrients. The continued investigation of gene-nutrient interactions responsible for this health problem will be important for several reasons. First, diseases such as obesity and associated complications result from undefined and complex interactions between susceptibility gene variants and various environmental factors [116]. The obesity susceptibility genes described in this review article interact with nutrients to either increase consumption of saturated fat or refined carbohydrates and to alter regulation of central metabolism pathways to increase weight $[117,118]$. Second, the identification of gene-nutrient interactions should be at the forefront in attempts to understand the etiology and pathophysiology of nutrition-related diseases, particularly obesity [119]. Third, the interaction of obesity susceptibility genes with nutrients will allow for more effective individual, family, and community preventative lifestyle intervention and eventually development of targeted nutritional or medicinal therapies $[120,121]$. Therefore, the overarching goal for investigating gene-nutrient interactions is to provide a plausible physiological approach to personalized nutritional or medicinal therapy that will more effectively address the current epidemic of common obesity.

\section{Abbreviations \\ APOA2: Apolipoprotein A2; BMI: Body mass index; FDA: Food and Drug Administration; FTO: Fat mass and obesity associated; GWAS: Genome-wide association study; HDL: High-density lipoprotein; HPFS: Health Professionals Follow-Up Study; MC4R: Melanocortin 4 receptor; NHS: Nurse's Health Study; NPC1: Niemann-Pick C1 \\ Funding \\ This work was supported in part by the National Center for Research Resources and the National Center for Advancing Translational Sciences of the National Institutes of Health (NIH) through grant number UL1 TR000041, a grant from Dedicated Health Research Funds of the University of New Mexico School of Medicine, and private funding through the University of New Mexico Foundation for the investigation of genetic and metabolic diseases.}

Availability of data and materials

Authors will make any data relevant to this review article available upon request.

Authors' contributions

$J J C$ contributed to the manuscript writing and editing and figure generation. RO and WSG contributed to the manuscript writing and editing. All authors read and approved the final manuscript.

Ethics approval and consent to participate

Not applicable for this publication.

Consent for publication

Authors declare consent for publication.

Competing interests

The authors declare that they have no competing interests.

\section{Publisher's Note}

Springer Nature remains neutral with regard to jurisdictional claims in published maps and institutional affiliations. 
Received: 17 January 2017 Accepted: 4 July 2017

Published online: 30 October 2017

\section{References}

1. Ogden $\mathrm{CL}$, Carroll MD, Kit BK, Flegal KM. Prevalence of childhood and adult obesity in the United States, 2011-2012. J Am Med Asso. 2014;311:806-14.

2. Berndt SI, Gustafsson S, Magi R, Ganna A, Wheeler E, Feitosa MF, et al. Genome-wide meta-analysis identifies 11 new loci for anthropometric traits and provides insights into genetic architecture. Nat Genet. 2013:45:501-12.

3. Bian L, Traurig M, Hanson RL, Marinelarena A, Kobes S, Muller YL, et al. MAP2K3 is associated with body mass index in American Indians and Caucasians and may mediate hypothalmic inflammation. Hum Mol Genet. 2013:22:4438-49

4. Bradfield JP, Taal HR, Timpson NJ, Scherag A, Lecoeur C, Warrington NA, et al. A genome-wide association meta-analysis identifies new childhood obesity loci. Nat Genet. 2012;44:526-31.

5. Kilpelainen TO, Zillikens MC, Stancakova A, Finucane FM, Ried JS, Langenberg C, et al. Genetic variation near IRS1 associates with reduced adiposity and an impaired metabolic profile. Nat Genet. 2011:43:753-60.

6. Locke AE, Kahali B, Berndt SI, Justice AE, Pers TH, Day FR, et al. Genetic studies of body mass index yield new insights for obesity biology. Nature. 2015:518:197-206.

7. Meyre D, Delplanque J, Chevre JC, Lecoeur C, Lobbens S, Gallina S, et al. Genome-wide association study for early-onset and morbid adult obesity identifies three new risk loci in European populations. Nat Genet. 2009;41:157-9.

8. Minster RL, Hawley NL, Su CT, Sun G, Kershaw EE, Cheng H, et al. A thrify variant in CREBRF strongly influences body mass index in Samoans. Nat Genet. 2016;48:1049-54.

9. Monda KL, Chen GK, Taylor KC, Palmer C, Edwards TL, Lange LA, et al. A meta-analysis identifies new loci associated with body mass index in individuals of African ancestry. Nat Genet. 2013:45:690-6.

10. Scherag A, Dina C, Hinney A, Vatin V, Scherag S, Vogel CIG, et al. Two new loci for body-weight regulation identified in a joint analysis of genomewide association studies for early-onset extreme obesity in French and German study groups. PLoS Genet. 2010;6:e10000916.

11. Speliotes EK, Willer CJ, Berndt SI, Monda KL, Thorleifsson G, Jackson AU, et al. Association analyses of 249,796 individuals reveal 18 new loci associated with body mass index. Nat Genet. 2010;42:937-48.

12. Thorleifsson G, Walters GB, Gudbjartsson DF, Steinthorsdottir $V$, Sulem $P$, Helgadottir A, et al. Genome-wide association yields new sequence variants at seven loci that associate with measures of obesity. Nat Genet. 2009;41(1): $18-24$

13. Wen W, Cho YS, Zheng W, Dorajoo R, Kato N, Qi L, et al. Meta-analysis identifies common variants associated with body mass index in east Asians. Nat Genet. 2012:44:307-11

14. Willer CJ, Speliotes EK, Loos RJF, Li S, Lindgren CM, Heid IM, et al. Six new loci associated with body mass index highlight a neuronal influence on body weight regulation. Nat Genet. 2009:41(1):25-34

15. Abadi A, Peralta-Romero J, Suarez F, Gomez-Zamudio J, Burguete-Carcia Al Cruz $M$, et al. Assessing the effects of 35 European-derived BMl-associated SNPs in Mexican Children. Obesity. 2016;24:1989-95.

16. Ahmad S, Zhao W, Renstrom F, Rasheed A, Samuel M, Zaidi M, et al. Physical activity, smoking, and genetic predisposition to obesity in people from Pakistan: the PROMIS study. BMC Med Genet. 2015;16:114

17. Hagg S, Ganna A, Van der Laan S, Esko T, Pers TH, Locke AE, et al. Genebased meta-analysis of genome-wide association studies implicates new loci involved in obesity. Hum Mol Genet. 2015;24:6849-60.

18. Hester JM, Wing MR, Li J, Palmer ND, Xu J, Hicks PJ, et al. Implication of European-derived adiposity loci in African Americans. Int J Obes. 2012;36:465-73.

19. Pigeyre M, Yazdi FT, Kaur Y, Meyre D. Recent progress in genetics, epigenetics and metagenomics unveils the pathophysiology of human obesity. Clin Sci. 2016;130:943-86.

20. Nakamura S, Narimatsu H, Sato H, Sho R, Otani K, Kawasaki R, et al. Geneenvironment interactions in obesity: Implication for future applications in preventive medicine. J Hum Genet. 2015;61:317-22.

21. Nettleton JA, Follis JL, Ngwa JS, Smith CE, Ahmad S, Tanaka T, et al. Gene x dietary pattern interactions in obesity: Analysis of up to 68,317 adults of European ancestry. Hum Mol Genet. 2015;24:4728-38.

22. Reddon H, Gerstein HC, Engert JC, Mohan V, Bosch J, Desai D, et al. Physical activity and genetic predisposition to obesity in a multiethnic longitudinal study. Sci Rep. 2016;6:18672.
23. Joffe YT, Houghton CA. A novel approach to the nutrigenetics and nutrigenomics of obesity and weight management. Curr Oncol Rep. 2016;18:43.

24. Franks PW, McCarthy MI. Exposing the exposures responsible for type 2 diabetes and obesity. Science. 2016;354:69-73.

25. Huang R, Moudon AV, Cook AJ, Drewnowski A. The spatial clustering of obesity: does the built environment matter? J Hum Nutr Diet. 2015;28:604-12.

26. Llewellyn C, Wardle J. Behaviorial susceptibility to obesity: Geneenvironment interplay in the development of weight. Physiol Behav. 2015; 152:494-501.

27. Hill JO, Wyatt HR, Peters JC. Energy balance and obesity. Circulation. 2012; 126:126-32.

28. Christiansen E, Swann A, Sorensen TIA. Feedback models allowing estimation of thresholds for self-promoting body weight gain. J Theor Biol. 2008;254:731-6.

29. Sorensen TIA. Challenges in the study of causation of obesity. Proc Nutr Soc. 2009;68:43-54.

30. Hill JO, Levine JS, Saris WHM. Energy expenditure and physical activity. In: Bray G, Bouchard C, editors. Handbook of Obesity. 2nd ed. New York: Marce Dekker, Inc; 2003. p. 631-54.

31. Choquet H, Meyre D. Genetics of obesity: What have we learned? Curr Genom. 2011;12:169-79.

32. Clark PJ. The heritability of certain anthropometric characters as ascertained from measurements of twins. Am J Hum Genet. 1956:8:49-54.

33. Borjeson M. The aetiology of obesity in children: a study of 101 twin pairs. Acta Paediatr Scand. 1976;65:279-87.

34. Brook CGD, Huntley RMC, Slack J. Influence of heredity and environment in determination of skinfold thickness in children. Br Med J. 1975:2:719-21.

35. Feinleib M, Garrison RJ, Fabsitz R, Christian JC, Hrubec Z, Borhani NO, et al. The NHLBI twin study of cardiovascular disease risk factors: Methodology and summary of results. Am J Epidemiol. 1977;106:284-95.

36. Wardle J, Carnell S, Haworth CMA, Plomin R. Evidence for a strong genetic influence on childhood adiposity despite the force of the obesogenic environment. Am J Clin Nutr. 2008:87:398-404.

37. Elks CE, den Hoed M, Zhao JH, Sharp SJ, Wareham NJ, Loos RJF, et al. Variability in the heritability of body mass index: a systematic review and meta-regression. Front Endocrinol. 2012;3:29.

38. Bouchard C. Childhood obesity: are genetic differences involved? Am J Clin Nutr. 2009;89:1494-501.

39. Bouchard C, Tremblay A, Despres JP, Nadeau A, Lupien PJ, Theriault G, et al. The response to long-term overfeeding in identical twins. N Engl J Med. 1990;322:1477-82

40. Segal NL, Allison DB. Twins and virtual twins: bases of relative body weight revisited. Int J Obes. 2002;26:437-41.

41. Reilly JJ, Armstrong J, Dorosty AR, Emmett PM, Ness A, Rogers I, et al. Early life risk factors for obesity in childhood: cohort study. BMJ. 2005;330:1357-63.

42. Day FR, Loos RJR. Developments in obesity genetics in the era of genomewide association studies. J Nutrigenet Nutrigenomics. 2011;4:222-38.

43. Dudley O, McManus B, Vogels A, Whittington J, Muscatelli F. Cross-cultura comparisons of obesity and growth in Prader-Willi Syndrome. J Intellect Disabil Res. 2008;52:426-36.

44. Guo G, Liu H, Wang L, Shen H, Hu W. The genome-wide influence on human BMI depends on physical activity, life course, and historical period. Demography. 2015;52:1651-70.

45. Vaisse C, Clement K, Durand E, Hercberg S, Guy-Grand B, Froguel P. Melanocortin-4 receptor mutations are a frequent and heterogenous cause of morbid obesity. J Clin Invest. 2000;106:253-62.

46. Pritchard JK. Are rare variants responsible for susceptiblity for complex diseases? Am J Hum Genet. 2001;69:124-37.

47. Reich DE, Lander ES. On the allelic spectrum of human disease. Trends Genet. 2001;17:502-10.

48. Hindorff LA, Sethupathy P, Junkins HA, Ramos EM, Mehta JP, Collins FS, et al. Potential etiologic and functional implications of genome-wide associatino loci for human diseases and traits. Proc Natl Acad Sci USA. 2009; 106:9362-7.

49. Li S, Zhao JH, Luan J, Luben RN, Rodwell SA, Khaw KT, et al. Cumulative effects and predictive value of common obesity-susceptibility variants identified by genome-wide association studies. Am J Clin Nutr. 2010;91: 184-90.

50. Gibson G. Hints of hidden heritablity in GWAS. Nat Genet. 2010:42:558-60

51. Maher B. The case of the missing heritability. Nature. 2008;456:18-21. 
52. McCarthy MI, Abecasis GR, Cardon LR, Goldstein DB, Little J, loannidis JPA, et al. Genome-wide association studies for complex traits: consensus, uncertainty and challenges. Nature. 2008;9:356-69.

53. Manolio TA. Genomewide association studies and assessment of the risk of disease. N Engl J Med. 2010;363:166-76.

54. Manolio TA, Collins FS, Cox NJ, Goldstein DB, Hindorff LA, Hunter DJ, et al. Finding the missing heritability of complex diseases. Nature. 2009:461:747-53.

55. Slatkin M. Linkage disequilibrium - understanding the evolutionary past and mapping the medial future. Nature. 2008;9:477-85.

56. Anderson CA, Soranzo N, Zeggini E, Barrett JC. Synthetic associations are unlikely to account for many common disease genome-wide association signals. PLoS Biol. 2011;9:e1000580.

57. Lassard S, Manning AK, Low-Kam C, Auer PL, Giri A, Graff M, et al. Testing the role of predicted gene knockouts in human anthropometric trait variation. Hum Mol Genet. 2016;25:2082-92.

58. Orozco G, Barrett JC, Zeggini E. Synthetic associations in the context of genome-wide association scan signals. Hum Mol Genet. 2010;19:137-44.

59. Walter K, Min JL, Huang J, Crooks L, Memari Y, McCarthy S, et al. The UK10K project identifies rare variants in health and disease. Nature. 2015;526:82-90.

60. Zhu Q, Ge D, Heinzen EL, Dickson SP, Urban TJ, Zhu M, et al. Prioritizing genetic variants for causality on the basis of preferential linkage disequilibrium. Am J Hum Genet. 2012;91:422-34.

61. Zuk O, Hechter E, Sunyaev SR, Lander ES. The mystery of missing heritability: Genetic interactions create phantom heritablity. Proc Natl Acad Sci USA. 2012;109:1193-8.

62. Llewellyn CH, Trzaskoski M, Plomin R, Wardle J. Finding the missing heritablity in pediatic obesity: the contribution of genome-wide complex trait analysis. Int J Obes. 2013;37:1506-9.

63. Yang J, Bakshi A, Zhu Z, Hemani G, Vinkhuyzen AAE, Lee SH, et al. Genetic variance estimation with imputed variants finds neglible missing heritablity for human height and body weight. Nat Genet. 2015;47:1114-20.

64. Neel JV. Diabetes mellitus: a "thrifty" genotype rendered detrimental by "progress"? Am J Hum Genet. 1962;14:353-62.

65. Neel JV. The "Thrifty Genotype" in 1998. Nutr Rev. 1999;57:S2-9.

66. Speakman JR. A nonadaptive scenario explaining the genetic predisposition to obesity:The "predation release" hypothesis. Cell Metab. 2007;6:5-12.

67. Speakman JR. Evolutionary perspectives on the obesity epidemic: adaptive, maladaptive, and neutral viewpoints. Annu Rev Nutr. 2013;33:289-317.

68. Henneberg M, Grantham J. Obesity-A natural consequence of human evolution. Anthropol Rev. 2014;77:1-10.

69. Prentice AM, Hennig BJ, Fulford AJ. Evolutionary origins of the obesity epidemic: Natural selection of thrifty genes or genetic drift following predation release? Int J Obes. 2008;32:1607-10.

70. Wells JCK. The evolution of human fatness and susceptibility to obesity: an ethological approach. Biol Rev. 2006;81:183-205.

71. Robinson MR, Hemani G, Medina-Gomez C, Mezzavilla M, Esko T, Shakhbazov K, et al. Population genetic differentiation of hight and body mass index across Europe. Nat Genet. 2015;47:1357-62.

72. Gosling AL, Buckley HR, Matisoo-Smith E, Merriman TR. Pacific populations, metabolic disease and 'just-so stories': a critique of the 'thrifty genotype' hypothesis in oceania. Ann Hum Genet. 2015;79:470-80.

73. Wang G, Speakman JR. Analysis of positive selection at single nucleotide polymorphisms associated with body mass index does not support the "thrifty gene" hypothesis. Cell Metabol. 2016;24:531-41.

74. Myles S, Lea RA, Ohashi J, Chambers GK, Weiss JG, Hardouin E, et al. Testing the thrifty gene hypothesis: the Gly482Ser variant in PPARGC1A is associated with BMI in Tongans. BMC Med Genet. 2011;12:10.

75. Patrick K, Norman GJ, Calfas KJ, Sallis JF, Zabinski MF, Rupp J, et al. Diet, physical activity, and sedentary behaviors as risk factors for overweight in adolescence. Arch Pediatr Adolesc Med. 2004;158:385-90.

76. Chaput JP, Drapeau V, Poirier P, Teasdale N, Tremblay A. Glycemic instability and spontaneous energy intake: association with knowledge-based work. Psychosom Med. 2008:70:797-804.

77. Graves L, Stratton G, Ridgers ND, Cable NT. Comparison of energy expenditure in adolescents when playing new generation and sedentary computer games: cross sectional study. BMJ. 2007;335:1282-4.

78. Stroebele N, de Castro JM. Listening to music while eating is related to increases in people's food intake and meal duration. Appetite. 2006;47:285-9.

79. Temple JL, Giacomelli AM, Kent KM, Roemmich JN, Epstein LH. Television watching increases motivated responding for food and energy intake in children. Am J Clin Nutr. 2007:85:355-61.
80. Westerlund L, Ray C, Roos E. Associations between sleeping habits and food consumption patterns among 10-11-year-old children in Finland. Br J Nutr. 2009;102:1531-7.

81. Aeberli I, Beljean N, Lehmann D, Spinas GA, Zimmerman MB. The increase of fatty acid-binding protein aP2 in overweight and obese children: Interactions with dietary fat and impact on measures of subclinical inflammation. Int J Obes. 2008;32:1513-20.

82. Aeberli I, Molinari L, Spinas G, Lehmann R, I'Allemand D, Zimmerman MB. Dietary intakes of fat and antioxidant vitamins are predictors of subclinical inflammation in overweight Swiss children. Am J Clin Nutr. 2006;84:748-55.

83. Lin PH, Wang Y, Grambow SC, Goggins W, Almirall D. Dietary saturated fat intake is negatively associated with weight maintenance among the PREMIER participants. Obesity. 2012;20:571-5.

84. Corella D, Arnett DK, Tucker KL, Kabagambe EK, Tsai M, Parnell LD, et al. A high intake of saturated fatty acids strengthens the association between the fat mass and obesity-associated gene and BMI. J Nutr. 2011;141:2219-25.

85. Razquin C, Martinez JA, Martinez-Gonzalez MA, Bes-Rastrollo M. A 3-year intervention with a Mediterranean diet modified the association between the rs9939609 gene variant in FTO and body weight changes. Int J Obes. 2010;34:266-72.

86. Gross LS, Li L, Ford ES, Liu S. Increased consumption of refined carbohydrates and the epidemic of type 2 diabetes in the United States: An ecologic assessment. Am J Clin Nutr. 2004;79(5):774-9.

87. Malik VS, Popkin BM, Bray GA, Despres JP, Hu FB. Sugar-sweetened beverages, obesity, type 2 diabetes mellitus, and cardiovascular disease risk. Circulation. 2010;121:1356-64.

88. Malik VS, Schulze MB, Hu FB. Intake of sugar-sweetened beverages and weight gain: a systematic review. Am J Clin Nutr. 2006;84:274-88.

89. Rankinen T, Zuberi A, Chagnon YC, Weisnagel SJ, Argyropoulos G, Walts B, et al. The human obesity gene map: the 2005 update. Obesity. 2006;14:529-644.

90. Fernandez JR, Klimentidis YC, Dulin-Keita A, Casazza K. Genetic influences in childhood obesity: recent progress and recommendations for experimental designs. Int J Obes. 2012;36:479-84.

91. Hofker M, Wijmenga C. A supersized list of obesity genes. Nat Genet. 2010; 41:139-40.

92. Lu Y, Loos RJF. Obesity genomics: assessing the transferability of susceptiblity loci across diverse populations. Genome Med. 2013;5:55.

93. Castellani LW, Goto AM, Lusis AJ. Studies with apolipoprotein A-II transgenic mice indicate a role for HDLs in adiposity and insulin resistance. Diabetes. 2001;50:643-51.

94. Castellani LW, Nguyen CN, Charugundla S, Weinstein MM, Doan CX, Blaner WS, et al. Apolipoprotein All is a regulator of very low density lipoprotein metabolism and insulin resistance. J Biol Chem. 2008;283:11633-44.

95. Ferns GAA, Shelley CS, Stocks J, Rees A, Paul H, Baralle R, et al. A DNA polymorphism of the apoprotein All gene in hypertriglyceridaemia. Hum Genet. 1986;74:302-6.

96. Warden CH, Daluiski A, Bu X, Purcell-Huynh DA, De Meester C, Shieh BH, et al. Evidence for linkage of the apolipoprotein A-II locus to plasma apolipoprotein II and free fatty acid levels in mice and humans. Proc Natl Acad Sci USA. 1993;90:10886-90.

97. Corella D, Arnett DK, Tsai MY, Kabacambe EK, Peacock JM, Hixson JE, et al. The $-256 \mathrm{~T}>\mathrm{C}$ polymorphism in the apolipoprotein A-II gene promoter is associated with body mass index and food intake in the genetics of lipid lowering drugs and diet network study. Clin Chem. 2007;53:1144-52.

98. Corella D, Peloso G, Arnett DK, Demissie S, Cupples LA, Tucker K, et al. APOA2, dietary fat, and body mass index. Replication of a gene-diet interaction in 3 independent populations. Arch Intern Med. 2009;169: 1897-906.

99. Corella D, Tai ES, Sorli JV, Chew SK, Coltell O, Sotos-Prieto M, et al. Association between the APOA2 promoter polymorphism and body weight in Mediterranean and Asian populations: replication of a gene-saturated fat interaction. Int J Obes. 2011;35:666-75.

100. Smith CE, Ordovas JM, Sanchez-Moreno C, Lee YC, Garaulet M. Apolipoprotein A-II polymorphism: relationships to behavioural and hormonal mediator of obesity. Int J Obes. 2012;36(1):130-6.

101. Garver WS, Heidenreich RA, Erickson RP, Thomas MA, Wilson JM. Localization of the murine Niemann-Pick C1 protein to two distinct intracellular compartments. J Lipid Res. 2000;41:673-87.

102. Hsu SJ, Erickson RP, Zhang J, Garver WS, Heidenreich RA. Fine linkage and physical mapping suggests cross-over suppression with a retroposon insertion at the Npc1 mutation. Mamm Genome. 2000;11:774-8. 
103. Loftus SK, Morris JA, Carstea ED, Gu JZ, Cummings C, Brown A, et al. Murine model of Niemann-Pick $C$ disease: mutation in a cholesterol homeostasis gene. Science. 1997;277:232-5.

104. Jelinek D, Heidenreich RA, Erickson RP, Garver WS. Decreased Npc1 gene dosage in mice is associated with weight gain. Obesity. 2010;18:1457-9.

105. Jelinek D, Millward V, Birdi A, Trouard TP, Heidenreich RA, Garver WS. Npc1 haploinsufficiency promotes weight gain and metabolic features associated with insulin resistance. Hum Mol Genet. 2010;20:312-21.

106. Jelinek D, Castillo JJ, Heidenreich RA, Garver WS. The C57BL/6J NiemannPick $\mathrm{C} 1$ mouse model with decreased gene dosage is susceptible to increased weight gain when fed a high-fat diet: Confirmation of a gene-diet interaction. Gene. 2015;568:112-3.

107. Liu R, Zou Y, Hong J, Cao M, Cui B, Zhang H, et al. Rare loss-of-function variants in NPC1 predisposes to human obesity. Diabetes. 2017;66:935-47.

108. Castillo JJ, Jelinek D, Wei H, Gannon NP, Vaughan RA, Horwood LJ, et al. The Niemann-Pick C1 gene interacts with a high-fat diet to promote weight gain through differential regulation of central energy metabolism pathways. Am J Physiol Endocrinol Metab. 2017;Published on-line May 9, 2017.

109. Qi Q, Chu AY, Kang JH, Jensen MK, Curhan GC, Pasquale LR, et al. Sugarsweetened beverages and genetic risk of obesity. N Eng J Med. 2012;367: 1387-96.

110. Qi Q, Chu AY, Kang JH, Huang J, Rose LM, Jensen MK, et al. Fried food consumption, genetic risk, and body mass index: gene-diet interaction analysis in three US cohort studies. BMJ. 2014;348:1610

111. Chan RSM, Woo J. Prevention of overweight and obesity: How effective is the current public health approach. Int J Environ Res Public Health. 2010;7: 765-83.

112. Hafekost K, Lawrence D, Mitrou F, O'sullivan TA, Zubrick SR. Tackling overweight and obesity: does the public health message match the science? BMC Med. 2013;11:41.

113. Wang Y, Cai L, Wu Y, Wilson RF, Weston C, Fawole O, et al. What childhood obesity prevention programes work? A systematic review and meta-analysis. Obes Rev. 2015;16:547-65.

114. Kuhnen P, Clement K, Wiegand S, Blankenstein O, Gottesdiener K, Martini LL, et al. Proopiomelanocortin deficiency treated with a melanocortin-4 receptor agonist. N Eng J Med. 2016;375:240-6.

115. Faroogi IS, Jebb SA, Langmack G, Lawrence $\mathrm{E}$, Cheetham CH, Prentice AM, et al. Effects of recombinant leptin therapy in a child with congental leptin deficiency. N Eng J Med. 1999;341:879-84.

116. Perusse L, Bouchard C. Gene-diet interactions in obesity. Am J Clin Nutr. 2000;72:1285S-90S.

117. Bauer F, Elbers CC, Adan RAH, Loos RJF, Onland-Moret NC, Grobbee DE, et al. Obesity genes identified in genome-wide association studies are associated with adiposity measures and potentially with nutrient-specific food preference. Am J Clin Nutr. 2009;90:951-9.

118. Garver WS. Gene-diet interactions in childhood obesity. Curr Genom. 2011; 12:180-9.

119. Levin BE. Synergy of nature and nurture in the development of childhood obesity. Int J Obes. 2009;33:S53-S6.

120. Khoury MJ, Davis R, Gwinn M, Lindegren ML, Yoon P. Do we need genomic research for the prevention of common diseases with environmental causes? Am J Epidemiol. 2005;161:799-805.

121. Yang $\mathrm{Q}$, Khoury MJ. Evolving methods in genetic epidemiology. III. Gene-environment interaction in epidemiological research. Epidemiol Rev. 1997:19:33-43.

\section{Submit your next manuscript to BioMed Centra and we will help you at every step:}

- We accept pre-submission inquiries

- Our selector tool helps you to find the most relevant journal

- We provide round the clock customer support

- Convenient online submission

- Thorough peer review

- Inclusion in PubMed and all major indexing services

- Maximum visibility for your research

Submit your manuscript at www.biomedcentral.com/submit

) Biomed Central 